\section{A Radiation-induced Mutant with Resistance to Common Bacterial Blight Disease in Common Beans}

\author{
Mohamed F. Mohamed 1 , Dermot P. Coyne ${ }^{2}$, and Paul E. Read ${ }^{3}$ \\ Department of Horticulture, University of Nebraska, Lincoln, NE 68583-0724
}

Additional index words. Xanthomonas campestris pv. phaseoli, Phaseolus vulgaris, gamma radiation, breeding

\begin{abstract}
The leaf reaction of the Phaseolus vulgaris L. germplasm-UNECA $\left(M_{6}\right.$ mutant derived from the cultivar Chimbolito, Costa Rica), 'Chimbolito', BAC-6 (Brazil), XAN159 (Centro Internacional de Agricultura Tropical, Cali, Colombia), and 'PC-50' (Domican Republic)—to Xanthomonas campestris pv. phaseoli strain $\mathrm{V}_{4} \mathrm{~S}_{1}$ (Dominican Republic) were determined in two replicated trials conducted in a greenhouse in Lincoln, Neb. (Feb.Mar. and July-Aug. 1993). 'PC-50' and 'Chimbolito' were susceptible to $X c p$ strain $V_{4} S_{1}$ in both tests. UNECA, BAC-6, and XAN-159 had similar levels of resistance to Xcp in the July to August trial. However, in the February to March trial, the resistance of UNECA was greater than that of BAC-6 but less than that of XAN-159.
\end{abstract}

Common bacterial blight disease, incited by Xanthomonas campestris pv. phaseoli (Smith) Dye $(X c p)$, is a major disease of common bean (Phaseolus vulgaris L.) (Yoshii, 1980). Emphasis has been placed on breeding bean cultivars resistant to Xcp (Coyne and Schuster, 1983). Dry-bean lines and cultivars with moderately high levels of resistance to Xcp (Coyne and Schuster, 1983; McElroy, 1985; Scott and Michaels, 1992) have been developed from interspecific hybridization of P. vulgaris with P. acutifolius A. Gray (Alvarez et al., 1981; Honma, 1956; Parker, 1985; Thomas and Waines, 1984). A mutant $\left(\mathrm{M}_{4}\right)$ bean line A-8-40, produced by gamma radiation of a $P$. vulgaris 'Zarya', was resistant to $X c p$ strains in Bulgaria (Zogorcheva and Poriazov, 1983). Subsequently, a single major recessive gene was reported to control resistance to $X c p$ in crosses of resistant plants made in A-8-40 to navy bean lines at Michigan State Univ., East Lansing (Adams et al., 1988).

Received for publication 8 Aug. 1994. Accepted for publication 7 Feb. 1995. Published as paper 10818 Journal Series, Nebraska Agricultural Research Division. Research was conducted under the Title XII Bean/Cowpea Collaborative Research Support Program Project, Univ. of Nebraska, Univ. of Puerto Rico, and Dominican Republic under US-AID contract DNA-1310-G-SS-6008-00 and also under Nebraska Agricultural Research Division Project no. 20-036. We thank Anne K. Vidaver and Patricia Lambrecht, Dept. of Plant Pathology, Univ. of Nebraska, Lincoln, for the bacterial cultures used in this research. The cost of publishing this paper was defrayed in part by the payment of page charges. Under postal regulations, this paper therefore must be hereby marked advertisement solely to indicate this fact.

${ }^{1}$ Former Visiting Scientist. Currently, Associate Professor, Dept. of Horticulture, Univ. of Assiut, Assiut, Egypt.

${ }^{2}$ George Holmes Regents Professor.

${ }^{3}$ Professor and Head.

HortSCienCE, Vol. 30(3), June 1995 plants were inoculated with $X c p$ strain $\mathrm{V}_{4} \mathrm{~S}_{1}$ (Dominican Republic). The inoculum concen- tration was $1.5 \times 10^{7}$ colony-forming units $/ \mathrm{ml}$ in a $12.5 \mathrm{~mm}$ standard potassium buffer with $10 \mathrm{~mm}$ magnesium sulphate. We used the multiple-needle method of inoculation (Andrus, 1948). Two leaflets of each trifoliolate leaf were inoculated with $X c p$; the third leaflet was inoculated with only potassium buffer (control).

The disease reaction was recorded 15 days after inoculation by visual inspection as the percentage of the inoculated leaf area developing common bacterial blight symptoms, such as necrosis, water soaking, or chlorosis. The mean percentage of the inoculated leaf area with common blight symptoms was recorded for eight plants per replication. A combined analysis of variance over planting dates was performed using arcsin-transformed values, and treatment means were separated using Duncan's multiple range test at $P \leq 0.05$.

\section{Results}

The cultivar/line $\times$ planting date interaction $(P=0.006)$ was significant; thus, the means of cultivars/lines are presented separately for each planting date (Fig. 1). The mutant UNECA was resistant to $X c p$, but 'Chimbolito' and 'PC-50' were susceptible at both planting dates. The disease resistance of UNECA in the February planting was significantly greater than that of BAC-6 (resistant control). Only slight symptoms $(<2 \%$ inoculated leaf area with symptoms) developed on XAN-159 in the February planting. Similar levels of resistance $(>15 \%$ and $<20 \%$ inoculated leaf area with symptoms) were observed on UNECA, BAC-6, and XAN-159 in the July planting. In subsequent replicated (RCBD) greenhouse tests, the resistance of UNECA was confirmed with four isolates of $X c p$ from the Dominican Republic and Nebraska (A. Dursun, Univ. of Nebraska, Lincoln, unpublished data) and also under natural infection with $X c p$ in a replicated trial (RCBD) in the field in the Dominican Republic in the winter season (Eladio Arnaud Santana, Arroyo Loro Expt. Station, San Juan de la Maguana, Dominican Republic, unpublished information).

A genetic association was reported (Coyne et al., 1973) between late flowering and maturity and resistance to common blight in germplasm derived from a $P$. vulgaris $\times P$. acutifolius cross (Honma, 1956), but Mohan (1981) reported no association between these traits. Flowering and maturity of UNECA were 7 to 10 days earlier than that of 'Chimbolito' under greenhouse conditions at both planting dates (data not presented). Thus, in our study, earliness was associated with resistance to $X c p$ in the UNECA mutant.

A. Dursun (Univ. of Nebraska, unpublished data) determined that resistance to three strains of $X c p$ was by two complementary dominant genes in the cross of the UNECA mutant with 'Chimbolito'. This inheritance pattern for resistance differs from that of Adams et al. (1988), who reported a recessive gene determining resistance to other $X c p$ strains in crosses of a gamma-radiation-produced snapbean mutant A-8-40. 
The UNECA mutant line was derived from a tropical adapted meso-American cultivar and may be useful in breeding for resistance to $X c p$ under tropical conditions because of the poor adaptability in the tropics of common bacterial-blight-resistant germplasm developed in temperate regions (Beebe and Corrales,

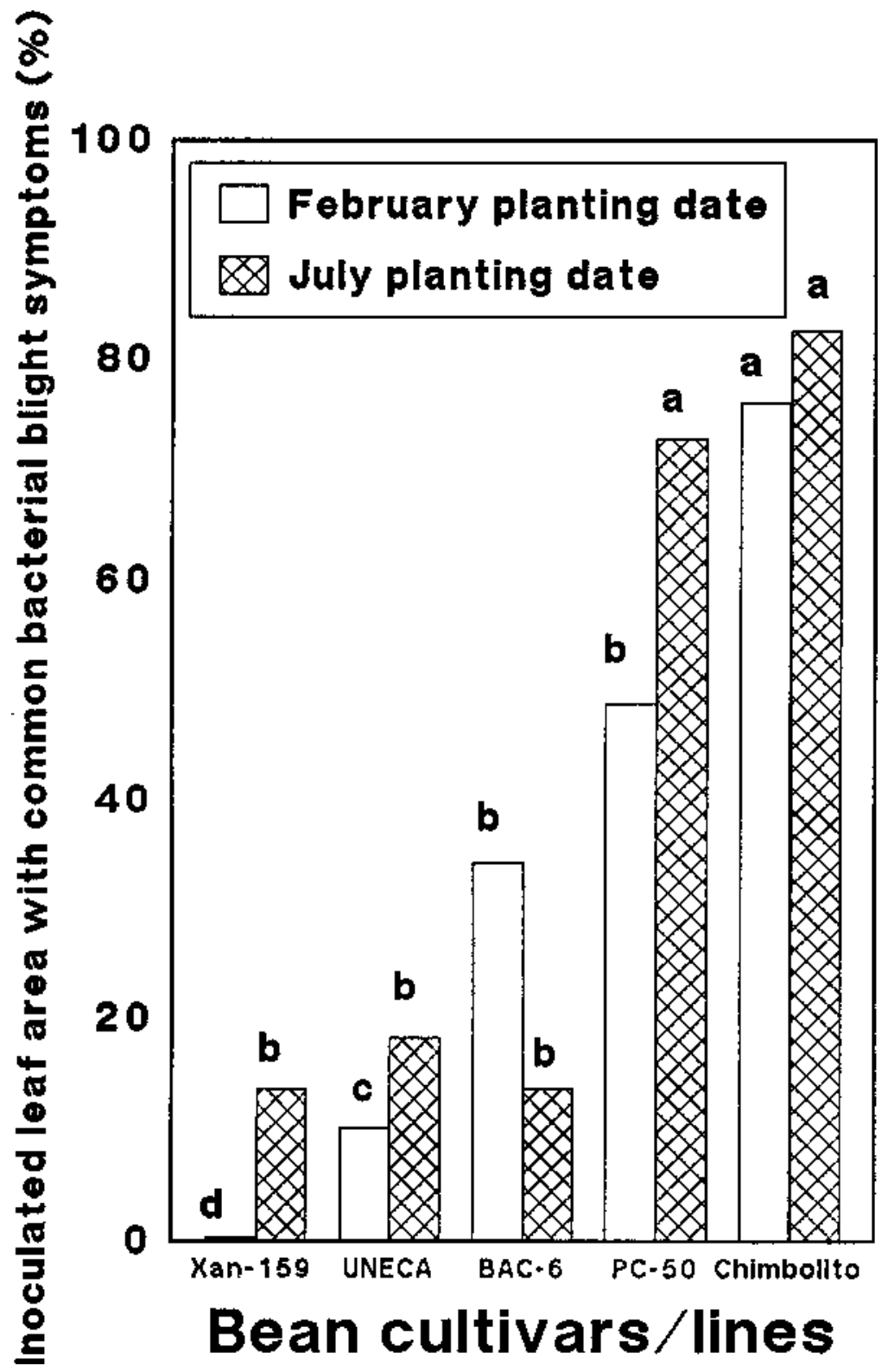

Fig. 1. Mean percentage of inoculated leaf area with common bacterial blight symptoms of common bean cultivars/lines at two planting dates. Mean separation for entries within a planting date by Duncan's multiple range test at $P \leq 0.05$. $X c p$ in progenies derived from commonblight-resistant bean germplasm originating from other bean species. UNECA may have a gene(s) for resistance to $X c p$ different from those in the currently available bean germplasm derived from $P$. acutifolius. If this dif-
1991). There was instability of resistance to

ference has a genetic basis, breeders may be able to recombine different genes from tepary germplasm with those from the UNECA and A-8-40 mutants (Adams et al., 1988) to develop greater levels of resistance to $X c p$.

\section{Literature Cited}

Adams, M.W., J.D. Kelly, and A.W. Saettler. 1988. A gene for resistance to common blight (Xanthomonas campestris pv. phaseoli). Annu. Rpt. Bean Improvement Coop. 31:73-74.

Alvarez, M.N., P.D. Ascher, and D.W. Davis. 1981. Interspecific hybridization in euphaseolus through embryo rescue. HortScience 16:541543.

Andrus, C.F. 1948. A method of testing beans for resistance to bacterial blights. Phytopathology 38:757-759.

Beebe, S.E. and M.P. Corrales. 1991. Breeding for disease resistance, p. 561-617. In: A.V. Schoonhoven and O. Voysest (eds.). Common bean: Research for improvement. Redwood Press, Melksham, Wilshire, U.K.

Coyne, D.P. and M.L. Schuster. 1983. Genetics of and breeding for resistance to bacterial pathogens in vegetable crops. HortScience 18:30-36.

Coyne, D.P., M.L. Schuster, and K. Hill. 1973. Genetic control of reaction to common blight bacterium in bean (Phaseolus vulgaris L.) as influenced by plant age and bacterial multiplication. Proc. Amer. Soc. Hort. Sci. 98:94-99.

Honma, S. 1956. A bean interspecific hybrid. J. Hered. 47:217-220.

McElroy, J.B. 1985. Breeding dry beans, Phaseolus vulgaris $\mathrm{L}$., for common bacterial blight resistance derived from Phaseolus acutifolius A. Gray. PhD Diss., Cornell Univ., Ithaca, N.Y.

Mohan, S.T. 1981. Breeding dry beans (Phaseolus vulgaris) for common bacterial blight resistance: Relation of "days to flowering" to blight reaction. Turrialba 31(2):109-112.

Parker, J.P.K. 1985. Interspecific transfer of common blight bacterial blight resistance from Phaseolus acutifolius A. Gray to P. vulgaris $\mathrm{L}$. MS Thesis, Univ. of Guelph, Guelph, Ont., Canada.

Scott, M.E. and T.E. Michaels. 1992. Xanthomonas resistance of Phaseolus interspecific cross selection confirmed by field performance. HortScience 27:348-350.

Thomas, C.V. and J.G. Waines. 1984. Fertile backcross and allotetraploid plants from crosses between tepary beans and common beans. J. Hered. 75:93-98.

Yoshii, K. 1980. Common and fuscous blights, p. 155-172. In: H.F. Schwartz and G.E. Galvez (eds.). Bean production problems. Centro Internacional de Agricultura Tropical, Cali, Colombia.

Zogorcheva, L. and I. Poriazov. 1983. Induction of mutation in green beans by gamma rays. Annu. Rpt. Bean Improvement Coop. 26:89-90. 